\title{
Colorectalis daganatokban \\ a 2-es típusú cukorbetegség és a thrombocytosis elófordulása, a túlélésre gyakorolt hatásuk, a primer tumor mǘtéti eltávolítása előtt és után
}

\author{
Herold Zoltán M.Sc. ${ }^{1}$ - Ambrus Viktória ${ }^{1}$ \\ Herold Magdolna ${ }^{1}$ - Herczeg György dr. ${ }^{3}$ - Igaz Péter dr. ${ }^{1}$ \\ Harsányi László dr. ${ }^{2}$. Somogyi Anikó dr. ${ }^{1}$ \\ Semmelweis Egyetem, Általános Orvostudományi Kar, \\ ${ }^{1}$ II. Belgyógyászati Klinika, ${ }^{2}$ I. Sebészeti Klinika, Budapest \\ ${ }^{3}$ Szent Imre Egyetemi Oktatókórház, Általános Sebészeti Profil, Budapest
}

\begin{abstract}
Bevezetés: Egyre több irodalmi adat utal a thrombocyták és a metasztatikus tumorsejtek kapcsolatára, illetve a pre- és posztoperatív thrombocytosis prediktív markerként való alkalmazhatóságára. Mind colorectalis daganatokban, mind 2-es típusú diabetesben jellemzőek a thrombocyták mennyiségi és/vagy minőségi károsodásai. 2-es típusú diabetesben a colorectalis tumorok emelkedett incidenciája ismert.

Célkitüzés: Retrospektív vizsgálatunk célja a Semmelweis Egyetem II. Belgyógyászati Klinikájának Onkológiai Ambulanciáján az elmúlt három évben kezelt colorectalis tumoros betegekben a 2-es típusú diabetes gyakoriságának meghatározása, illetve a daganatos betegség felismerésekor és a primer daganat mútéti eltávolítását követően a thrombocytaszámok, valamint további laboratóriumi és anamnesztikus adatok felmérése, továbbá statisztikai modellek segítségével vizsgálni a cukorbetegség túlélést befolyásoló hatását.

Módszer: 86, random kiválasztott colorectalis tumoros beteg pre- (86 fó) és posztoperatív (66 fó, mútétre alkalmas, párosított) adatait dolgoztuk fel. A betegeket legkésóbb 2017. szeptember 30-ig vagy haláluk bekövetkeztéig követtük. Eredmények: Emelkedett (400 giga/l feletti) thrombocytaszámokat figyeltünk meg a betegek 22,1\%-ában $(323,5 \pm$ $128,63$ giga/1, átlag $\pm S D)$, melyek a primer tumor mútéti eltávolítását követően $10,6 \%$-ra csökkentek $\left(\chi^{2}\right.$-teszt: $\mathrm{p}=0,035 \mathrm{l} ; 289,2 \pm 82,45$ giga/l, $\mathrm{p}=0,0232)$. Az emelkedett thrombocytaszámokhoz rövidebb túlélési idő́k tartoztak ( $\mathrm{R}:-0,35, \mathrm{p}=0,0085)$. Diabetes a betegek harmadában volt igazolható. A diabeteses és a nem diabeteses személyek vizsgált laboratóriumi paraméterei (például vérkép, vesefunkció, májenzimek) nem különböztek. A primer tumor sebészi eltávolítását követően a diabetes ötszörös kockázati tényezője a rövidebb túlélésnek (relatív kockázat: $5,1612, \mathrm{p}=0,0165)$. Az átlagos túlélési idő 30,6 $\pm 26,78$ hónap.

Következtetés: A következményes, tartósan fennálló thrombocytosis a műtét után kedvezőtlen túlélési időre utal. Megfigyeléseink alapján a colorectalis daganatok felismerésekor az emelkedett thrombocytaszám és a 2-es típusú diabetes prognosztikai markerek lehetnek.
\end{abstract}

Orv Hetil. 2018; 159(19): 756-767.

Kulcsszavak: vérlemezkék, thrombocytosis, colorectalis neoplazmák, diabetes mellitus, 2-es típus, túlélési elemzés

The occurrence and impact on survival of type 2 diabetes mellitus and thrombocytosis in colorectal cancer, before and after the surgical resection of the primary tumor

Introduction: The relationship between platelets and metastatic tumor cells is an ongoing research area. Pre- and postoperative thrombocytosis are suggested predictive survival markers. Colorectal cancer and type 2 diabetes are characterized by various changes to platelets. The occurrence of colorectal cancer is more frequent in diabetes. 
Aim: Our aim was to determine the occurrence of type 2 diabetes in colorectal cancer patients, who attended the Semmelweis University $2^{\text {nd }}$ Department of Internal Medicine's Oncology Department in the last three years. Further goals included the evaluation of anamnestic, pre- and postoperative laboratory data, and whether diabetes can be a significant survival factor.

Method: A retrospective study was conducted with 86 randomly selected colorectal cancer patients' preoperative (86 patients) and paired postoperative (66, who were operable) data. Patients were monitored no later than September 30, 2017 or until their death.

Results: Preoperatively, elevated (over $400 \mathrm{Giga} / \mathrm{L})$ platelet counts were present in $22.1 \%$ of the patients $(323.5 \pm$ $128.63 \mathrm{Giga} / \mathrm{L}$, mean $\pm \mathrm{SD})$ which decreased to $10.6 \%$ postoperatively $\left(\chi^{2}: \mathrm{p}=0.0351 ; 289.2 \pm 82.45 \mathrm{Giga} / \mathrm{L}\right.$, $\mathrm{p}=0.0232)$. Negative correlation was found between platelet counts and overall survival $(\mathrm{R}:-0.35, \mathrm{p}=0.0085)$. One third of the patients had diabetes. Laboratory results (i.e., blood counts, creatinine) between diabetic and nondiabetic patients were not significant. Diabetes is a significant five-fold postoperative risk factor for shorter overall survival (relative risk: $5.1612, \mathrm{p}=0.0165$ ). Average survival was $30.6 \pm 26.78$ months.

Conclusion: Persistent consequential postoperative thrombocytosis may indicate shorter survival time. Our observations suggest elevated platelet counts and type 2 diabetes as prognostic markers for survival at the recognition of colorectal tumors.

Keywords: blood platelets, thrombocytosis, colorectal neoplasms, diabetes mellitus, type 2, survival analysis

Herold Z, Ambrus V, Herold M, Herczeg Gy, Igaz P, Harsányi L, Somogyi A. [The occurrence and impact on survival of type 2 diabetes mellitus and thrombocytosis in colorectal cancer, before and after the surgical resection of the primary tumor]. Orv Hetil. 2018; 159(19): 756-767.

(Beérkezett: 2018. január 2.; elfogadva: 2018. február 10.)

\section{Rövidítések}

$\mathrm{CRC}=($ colorectal cancer $)$ vastag- és végbélrák; eGFR $=($ estimated glomerular filtration rate) számított glomerularis filtrációs ráta; $\mathrm{HbA}_{1 \mathrm{C}}=$ (glycated hemoglobin $)$ glikált hemoglobin; hsCRP $=($ high-sensitivity $\mathrm{C}$-reactive protein $)$ magas szenzitivitású C-reaktív protein; $\mathrm{LFU}=($ lost to follow-up) követés során elveszett; RDW = (red blood cell distribution width) vörösvértest-eloszlási szélesség; RR = (relative risk) relatív kockázat; $\mathrm{T} 2 \mathrm{DM}=$ (type 2 diabetes mellitus) 2 -es típusú diabetes mellitus

Armand Trousseau már az 1860-as évek második felében megfigyelte, hogy a gyomor-bél rendszeri tumorok gyakran társulnak thrombophlebitisszel. Mivel a vérrögök a tumortól jelentős távolságban voltak észlelhetők, feltételezte, hogy ez valamilyen, „a vér egyfajta különleges változása lehet” [1]. Bár a metasztatikus tumorsejtek és a thrombocyták közös aggregátumképzése a keringésben több mint 150 éve ismert, a jelenség pontos molekuláris háttere máig tisztázatlan. Számos genetikai és modell állatokkal végzett vizsgálat alapján a keringésbe lépő tumorsejtek sejtfelszínén specifikus, a thrombocyták tumorsejthez való kapcsolódását segítő, azaz thrombocytaaggregációt indukáló fehérjék jelennek meg [2-7]. E mechanizmus hiányában a tumorsejtek kevesebb mint 1\%-a élné csak túl a keringésben történő vándorlást [8, 9]. Számos tumortípusnál igazoltak magasabb thrombocytaszámokat, ilyenek például a vastag- és végbéltumorok (CRC). A magasabb thrombocytaszámokhoz jellemzően rosszabb túlélési esélyek tartoznak [1014]. A tumoros betegségekhez társuló thrombocytosis diagnózisának meghatározásához az irodalomban számos eltérő thrombocyta-határértéki adat található. A leggyakrabban alkalmazott thrombocytosis-határérték a laboratóriumok által is használt normáltartomány felső határa (400 giga/1), de ismertek ettől eltérő, további határértékek is az irodalomból [15].

A cukorbetegség világszerte jelentős egészségügyi és gazdasági probléma. Világszerte a lakosság körülbelül 8-9\%-a diabeteses, a betegek legnagyobb része, mintegy 90\%-a 2-es típusú cukorbeteg (T2DM) [16]. Nemzetközi becslések alapján a 60 év feletti korosztályban körülbelül minden ötödik személy szenved T2DM-ben [17]. A betegség magyarországi előfordulására vonatkozóan a Nemzeti Egészségbiztosítási Alapkezelő (korábban Országos Egészségbiztosítási Pénztár, OEP) nyilvántartásából, az antidiabetikumok kiváltásán alapuló becslés készült [18]: az elmúlt 15 évben a betegség hazai prevalenciája a másfélszeresére nőtt. A teljes magyar lakosság 7-8\%-a gyógyszerrel kezelt cukorbeteg. Életkor szerinti bontás alapján a 60 év feletti személyeknél a betegség előfordulási gyakorisága körülbelül $20 \%$ volt, azonban a felírt gyógyszert ki nem váltó, illetve a csak diétával kezelt T2DM-betegek számáról nincs elérhető adat. További limitáló tényezője mind a magyar, mind a nemzetközi statisztikáknak, hogy egyes társult betegségek kivételével, mint például a cardiovascularis események [17], a T2DM-mel közös, pontos előfordulási gyakoriságokról nincsenek elérhető adatok. Ilyen betegség például az általunk vizsgált CRC is, melynek az egészséges populációhoz képest másfélszeres kialakulási incidenciája ismert egyedül T2DM-ben [19]. 
Az egészséges populációhoz képest T2DM-ben a tumoros betegségek nagyobb előfordulási gyakorisága igazolt: szignifikánsan több pancreas-, CRC- és emlőtumoros esetet figyeltek meg. Számos elmélet született, hogy e megfigyelés hátterében különböző, a T2DM-et befolyásoló, illetve a betegség miatt kialakuló tényezők állhatnak, mint például a hyperglykaemia, az inzulinrezisztencia, a hyperinsulinaemia, a magasabb széruminzulin-szerü növekedési faktor-1 (IGFl) koncentrációja, a folyamatos gyulladásos állapotok miatti magasabb citokinkoncentrációk, az oxidatív stressz, a dyslipidaemia vagy a fokozott thrombocytaaktiváció [20-25]. A T2DM-betegek kezelése során alkalmazott különböző antidiabetikumok tumorokkal szembeni védő- vagy éppen azok növekedését serkentő hatása jelenleg is számos klinikai gyógyszervizsgálat tárgyát képezi [21]. A legtöbb vizsgálat - a feltételezett tumorvédő hatása miatt a metforminnal kapcsolatban folyt/folyik [26, 27]. A T2DM-ben ismert fokozott thrombocytaaktiváció miatt a betegek jelentős hányadánál alkalmaznak preventív céllal thrombocytaaggregáció-gátló kezelést is (acetilszalicilsav, klopidogrel stb.) $[28,29]$.

\section{A vizsgálat célja}

Retrospektív elemzésünk során arra kerestük a választ, hogy a Semmelweis Egyetem II. Belgyógyászati Klinikájának Onkológiai Ambulanciáján 2014 és 2017 között vizsgált és kezelt, CRC-ben szenvedő betegpopulációban milyen arányban fordul elő T2DM. A betegek a tumor felfedezésekor milyen laboratóriumi, illetve anamnesztikus adatokkal rendelkeznek? Az egyes vizsgált paraméterek között milyen összefüggések igazolhatók?

Vizsgáltuk, hogy van-e kimutatható különbség a nem T2DM-tumoros és a T2DM-tumoros betegek egyes laboratóriumi és anamnesztikus paraméterei között. A CRC-re jellemző thrombocytosis, az áttétek és/vagy egyéb betegségek milyen arányban vannak jelen a két betegcsoportban? A primer tumor eltávolítását követően változnak-e az egyes paraméterek az összes betegben együttesen, illetve a T2DM- és a nem T2DM-betegcsoportban külön-külön? Egy- és többtényezős túlélési modellek segítségével igazolható-e, hogy a T2DM egy, a tumoros betegek túlélését befolyásoló tényező?

\section{Módszer}

\section{Betegek}

Retrospektív vizsgálatunkat a Semmelweis Egyetem II. számú Belgyógyászati Klinikájának Onkológiai Ambulanciáján az elmúlt 3 évben megjelent 120, CRC miatt kezelt beteg klinikai adatainak felhasználásával végeztük. A kiértékelt laboratóriumi vizsgálatok a tumor sebészi eltávolítása és bárminemú radiokemoterápiás kezelés megkezdése előtt, illetve a primer tumor mútéti eltávolí- tását követően 4-6 héttel, de még a kemoterápiás kezelés indítása elött történtek. A hiányos adattal rendelkező esetek - például nem érhetők el a beteg adott megjelenéséhez tartozó laboratóriumi leletek - kiszürését követően a statisztikai elemzéseink során végül 86 beteg műtét előtti adatait elemeztük. Vizsgáltuk, hogy a primer daganat eltávolítását követően a laboratóriumi paraméterek változnak-e. A mütétet követően 66 betegnél volt elérhető, párosított adat. Ennek egyik oka az, hogy idősebb, rosszabb általános állapotú betegeknél nem történt mütét annak kontraindikációja miatt, másik oka az inoperabilitás vagy a sikertelen tumoreltávolíthatóság a mütét során (például carcinosis peritonei miatt). A mütétet követő korai kemoterápiás kezelés indítása (6 hétnél hamarabb) vagy a betegek más intézményben (például körzetben) történő további kezelése miatt szintén jelentősen csökken(het) a feldolgozható esetek száma a mütétet követően.

A vizsgálatban részt vevő betegekben vizsgáltuk a primer tumor felfedezésekor a vérképet - különös tekintettel a thrombocytaértékekre -, az éhomi vércukorszinteket, a máj- és vesefunkció paramétereit, a magas szenzitivitású C-reaktív proteint (hsCRP), valamint a T2DM fennállási idejét, a betegeknek a tumor felfedezését követő túlélési idejét. A laboratóriumi paraméterek mellett felmértük a betegeknél a tumoros betegség mellett jelen lévő egyéb betegségek, mint például magas vérnyomás, pajzsmirigybetegségek, major cardiovascularis események stb. előfordulását is.

A cukorbetegek általános cukoranyagcsere-állapotát leginkább a glikált hemoglobin $\left(\mathrm{HbA}_{\mathrm{lC}}\right)$ értékeivel jellemezhetjük. Az archív adatok között igen kevés esetben történt $\mathrm{HbA}_{1 \mathrm{C}}$-mérés, emiatt a többi paraméterrel történő összehasonlítását jelen vizsgálatunkban nem tudtuk elvégezni.

A laboratóriumi leleteken a számított glomerularis filtrációs ráta (eGFR) értéke $90 \mathrm{ml} / \mathrm{min} / 1,73 \mathrm{~m}^{2}$ felett (régebbi leleteken $60 \mathrm{ml} / \mathrm{min} / 1,73 \mathrm{~m}^{2}$ felett) általában nincs feltüntetve. Emiatt a pontos eGFR-értékeket minden esetben a 4 változós MDRD-képlet („175-ös” formula) alapján [30], manuálisan számítottuk ki.

\section{Statisztikai elemzések}

Statisztikai elemzéseinket az $\mathrm{R}$ for Windows version 3.4 .2 [31] és az RStudio version 1.1.383 [32] programmal végeztük. Az adatok elemzéséhez felhasználtunk parametrikus és nem parametrikus elemzéseket; a paraméterek normalitását grafikus módszerekkel és ShapiroWilk-teszttel ellenőriztük. A csoportok közötti összehasonlításokhoz kétmintás és párosított Welch-féle t-tesztet, Wilcoxon-Mann-Whitney-féle U-tesztet, Wilcoxon-féle előjeles rangpróbát, a gyakoriságelemzésekhez Yates-korrekcióval alkalmazott $\chi^{2}$-teszteket, míg az összefüggések elemzéséhez Spearman-korrelációs elemzéseket végeztünk. A kapott p-értékek korrekcióját FDR-módszerrel végeztük el [33-36]. 


\section{Túlélési elemzések}

A betegek túlélési idejét a mütétet megelőző vérvétel időpontjától a beteg haláláig vagy a túlélők esetében 2017. szeptember 30-ig számoltuk. Túlélési elemzések során az úgynevezett nem informatív cenzorálási módszer alkalmazása követendő, mely alapján a „követés során elveszett” (LFU) vizsgálati alanyok és a végpont (esetünkben halálozás) bekövetkezése miatti, úgynevezett cenzoresemények nem különítendők el. A statisztikai eredmények torzulása és a vizsgálat megbízhatósága végett az LFU-esetek minimalizálására kell törekedni. Kis LFU-arány esetén az LFU-alany(ok) vizsgálatból történő kizárására nincs szükség [37]. Adataink feldolgozása során az elhunyt betegek mellett a 7 LFU-esetben (a vizsgálati személyek 8\%-a) a túlélési időt az Egyetem bármely klinikáján történt legutolsó megjelenésig számoltuk. Például amikor a beteget a körzetben kezelték tovább, és sem telefonon, sem egyéb módon nem tudtunk érdemi információt beszerezni.

Egy- és többváltozós túlélési elemzésekkel is vizsgáltuk, hogy a különböző paraméterek miként befolyásol(hat)ják a betegek túlélését. Mind a primer tumor mütéti eltávolítása előtti, mind az azt követően elérhető adatok felhasználásával elvégeztük az elemzéseket. Egyváltozós túlélési elemzéssel (Kaplan-Meier-féle túlélésanalízis) a T2DM önálló, túlélésre gyakorolt hatását vizsgáltuk. A többváltozós elemzésekkel (Cox-regresszió vagy arányos kockázati analízis) az életkor, a thrombocytaszámok, az anaemiára utaló vörösvértest-eloszlási szé- lesség (RDW) és a vesefunkciót jellemző eGFR- és kreatininszintek, illetve az áttétek, a kezelt magas vérnyomás és a T2DM jelenlétének túlélésre gyakorolt együttes hatását vizsgáltuk ( $\mathrm{R}$ survival és survminer csomag [38, 39]). A túlélési modellek diagnosztikus ellenőrzése minden esetben megtörtént [40].

\section{Etikai engedély}

A fenti vizsgálatokat az Egészségügyi Tudományos Tanács Tudományos és Kutatásetikai Bizottsága (ETTTUKEB, engedélyszám: 8951-3/2015/EKU) és a Semmelweis Egyetem Tudományos Etikai Bizottsága (SE-TUKEB, engedélyszám: 21-12/1994) is engedélyezte.

\section{Eredmények}

\section{A vizsgált paraméterek elemzése a primer tumor mütéti eltávolitását megelözồn}

Retrospektív vizsgálatunkban 86, CRC miatt kezelt beteg mútét előtti adatait elemeztük. A betegeket a T2DM megléte alapján 2 csoportba rendeztük. A tumoros és T2DM-személyek csoportjába 23-an (T2DM-csoport), míg a tumoros és nem T2DM-személyek csoportjába 63-an (nem-DM-csoport) kerültek besorolásra.

T2DM a betegek nagyjából 30\%-ában állt fenn, mely a tumor kialakulása előtt átlagosan 9,4 $\pm 4,58$ évvel alakult

1. táblázat $\mid$ Az összes beteg, illetve a cukorbeteg- (T2DM-) és a nem cukorbeteg- (nem-DM-) csoport laboratóriumi paraméterei a primer tumor felfedezésekor, annak mútéti eltávolítását megelőzően (átlag \pm szórás)

\begin{tabular}{|c|c|c|c|c|}
\hline Paraméter & $\begin{array}{l}\text { Összes beteg } \\
\quad(\mathrm{n}=86)\end{array}$ & $\begin{array}{l}\text { nem-DM-csoport } \\
\qquad(\mathrm{n}=63)\end{array}$ & $\begin{array}{l}\text { T2DM-csoport } \\
(\mathrm{n}=23)\end{array}$ & $\begin{array}{c}\text { p-érték } \\
\text { (nem-DM vs. T2DM) }\end{array}$ \\
\hline Életkor [év] & $67,1 \pm 11,54$ & $66,5 \pm 12,49$ & $68,8 \pm 8,41$ & n. s. \\
\hline Fehérvérsejt [giga/l] & $8,6 \pm 3,16$ & $8,6 \pm 3,23$ & $8,7 \pm 3,03$ & n. s. \\
\hline Vörösvértest [tera/l] & $4,4 \pm 0,52$ & $4,5 \pm 0,48$ & $4,3 \pm 0,62$ & n. s. \\
\hline Hemoglobin $[\mathrm{g} / 1]$ & $121,0 \pm 24,34$ & $122,8 \pm 25,19$ & $115,8 \pm 21,52$ & n. s. \\
\hline Hematokrit $[1 / 1]$ & $0,37 \pm 0,052$ & $0,38 \pm 0,052$ & $0,36 \pm 0,052$ & n. s. \\
\hline Thrombocyta [giga/1] & $332,8 \pm 133,28$ & $335,6 \pm 138,09$ & $325,0 \pm 121,67$ & n. s. \\
\hline Vörösvértest-eloszlási szélesség (RDW) [\%] & $14,9 \pm 2,46$ & $15,1 \pm 2,64$ & $14,5 \pm 1,89$ & n. s. \\
\hline Glutamát-oxálacetát-transzamináz (GOT) [U/l] & $22,7 \pm 12,17$ & $24,3 \pm 13,24$ & $18,7 \pm 7,88$ & n. s. \\
\hline Glutamát-piruvát-aminotranszferáz (GPT) [U/1] & $24,2 \pm 19,94$ & $25,3 \pm 22,73$ & $21,2 \pm 9,27$ & n. s. \\
\hline Gamma-glutamil-transzferáz (GGT) [U/1] & $43,5 \pm 48,12$ & $43,7 \pm 54,02$ & $43,0 \pm 28,90$ & n. s. \\
\hline $\mathrm{eGFR}\left[\mathrm{ml} / \mathrm{min} / 1,73 \mathrm{~m}^{2}\right]$ & $76,3 \pm 24,63$ & $77,5 \pm 24,93$ & $72,9 \pm 24,04$ & n. s. \\
\hline Éhomi vércukor [mmol/l] & $6,1 \pm 1,68$ & $5,5 \pm 1,08$ & $7,5 \pm 2,09$ & $\mathrm{p}=0,0005$ \\
\hline $\mathrm{hsCRP}[\mathrm{mg} / \mathrm{l}]$ & $48,2 \pm 81,75^{*}$ & $49,8 \pm 87,82 *$ & $43,8 \pm 64,20 *$ & n. s. \\
\hline Diabetes fennállása [év] & - & - & $9,4 \pm 4,58$ & - \\
\hline Teljes túlélési idő [hónap] & $30,6 \pm 26,78$ & $31,9 \pm 28,26$ & $27,0 \pm 22,41$ & n. s. \\
\hline
\end{tabular}

*A magas szenzitivitású C-reaktív protein (hsCRP) értékei nem minden beteg esetében voltak elérhetők: a nem DM-csoportban 42 fó, míg a T2DM-csoportban 15 fó.

eGFR = számított glomerularis filtrációs ráta; $n$. s. = nem szignifikáns 
2. táblázat $\mid$ Az összes beteg, illetve a cukorbeteg- (T2DM-) és a nem cukorbeteg- (nem-DM-) csoport anamnesztikus adatai a primer tumor felfedezésekor, annak mútéti eltávolítását megelőzően

\begin{tabular}{|c|c|c|c|c|}
\hline Paraméter & $\begin{array}{l}\text { Összes beteg } \\
\quad(\mathrm{n}=86)\end{array}$ & $\begin{array}{l}\text { nem-DM-csoport } \\
\quad(\mathrm{n}=63)\end{array}$ & $\begin{array}{l}\text { T2DM-csoport } \\
\qquad(\mathrm{n}=23)\end{array}$ & $\begin{array}{c}\text { p-érték } \\
(\text { nem-DM vs. T2DM) }\end{array}$ \\
\hline Diabetes [\%] & 26,7 & - & - & - \\
\hline Áttét [\%] & 38,4 & 36,5 & 43,5 & n. s. \\
\hline Hypertonia [\%] & 68,6 & 57,1 & 100 & $\mathrm{p}<0,0001$ \\
\hline $\begin{array}{l}\text { Major cardiovascularis esemény [\%] } \\
\text { (a tumor felismerése elött) }\end{array}$ & 20,9 & 20,6 & 21,7 & n. s. \\
\hline Pajzsmirigybetegség [\%] & 9,3 & 11,1 & 4,4 & n. s. \\
\hline Thrombocytosis $400+[\%]$ & 22,1 & 25,4 & 13 & $\mathrm{p}=0,0416$ \\
\hline Elhunyt betegek [\%] & 30,2 & 30,2 & 30,4 & n. s. \\
\hline Cenzorált esetek (halál + eltűnés) [\%] & 39,5 & 36,5 & 47,8 & n. s. \\
\hline
\end{tabular}

n. s. = nem szignifikáns

A: Thrombocytaszám vs. túlélési idő

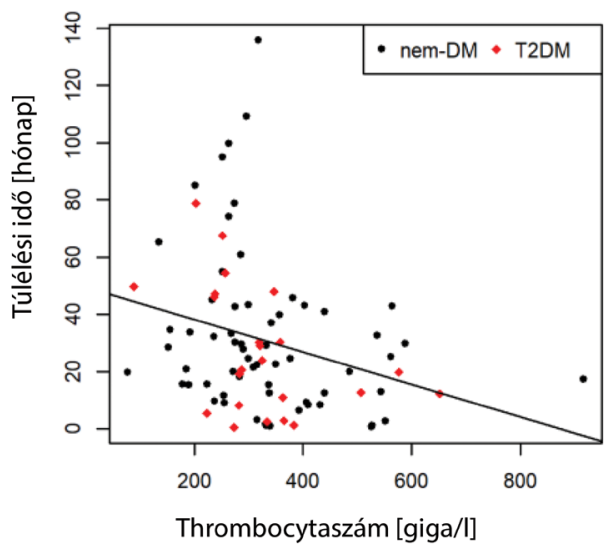

B: Thrombocytaszám vs. fehérvérsejtszám

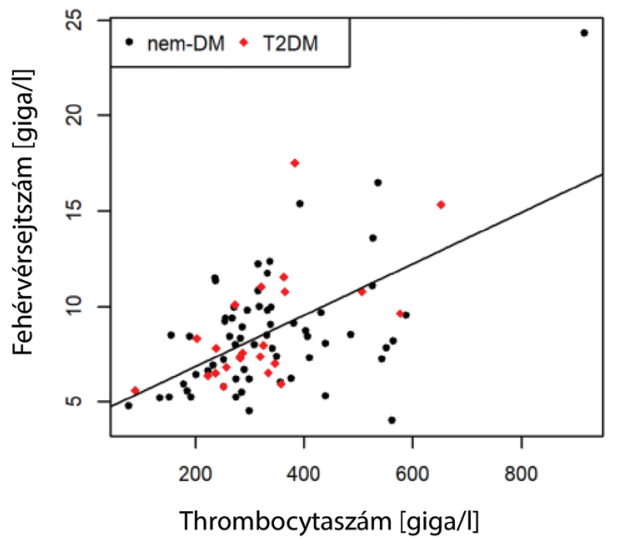

C: Túlélési idő vs. fehérvérsejtszám

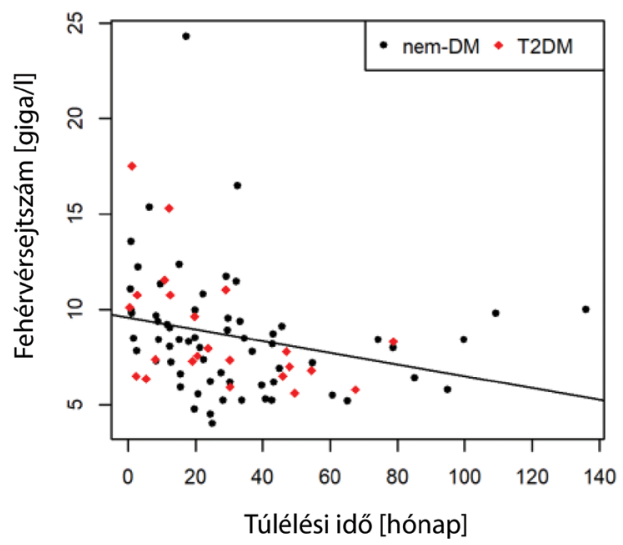

1. ábra $\mid$ Az összes betegnél $(\mathrm{n}=86)$ mért thrombocytaszámok korrelációs összefüggése A: a túlélési idővel $(\mathrm{R}:-0,35, \mathrm{p}=0,0085)$ és B: a fehérvérsejtszámokkal $(\mathrm{R}:+0,42, \mathrm{p}=0,0007)$, illetve $\mathrm{C}$ : a túlélési idő és a fehérvérsejtszám közötti összefüggések $(\mathrm{R}:-0,41, \mathrm{p}=0,0010)$

ki. A T2DM- és a nem-DM-csoport között a primer tumor műtéti eltávolítását megelőző laboratóriumi paraméterek az éhgyomri vércukorszintek (nem-DM: 5,5 \pm $1,08 \mathrm{mmol} / 1, \mathrm{~T} 2 \mathrm{DM}: 7,5 \pm 2,09 \mathrm{mmol} / \mathrm{l}, \mathrm{p}=0,0005)$ kivételével nem különböztek (1. táblázat). Míg a nemDM-betegek 70\%-a kezelt hypertoniás, addig a T2DM- csoportban az összes beteg kezelt hypertoniás (nem-DM 36: fo, T2DM: 23 fó, $\mathrm{p}<0,0001$ ) volt. A thrombocytosis (400 giga/l-t meghaladó thrombocytaszám, SE Központi Laboratórium normáltartománya: 150-400 giga/l) szignifikánsan ritkább volt a T2DM-csoportban (nem-DM: 16 fó, T2DM: 3 fö, p<0,0001). A tumoros 

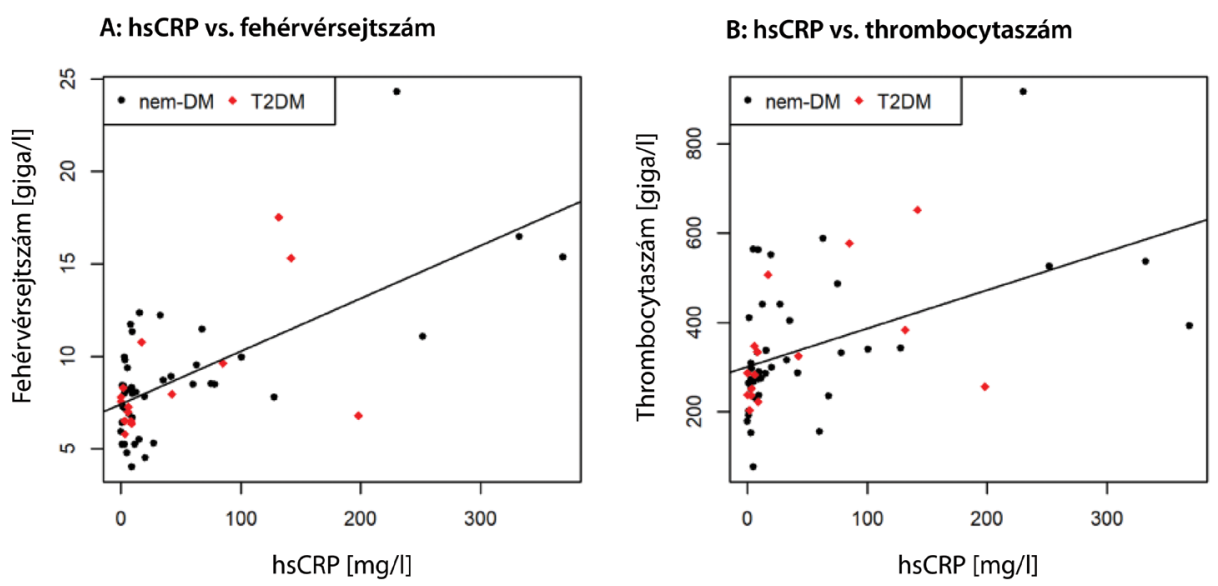

C: hsCRP vs. túlélési idő

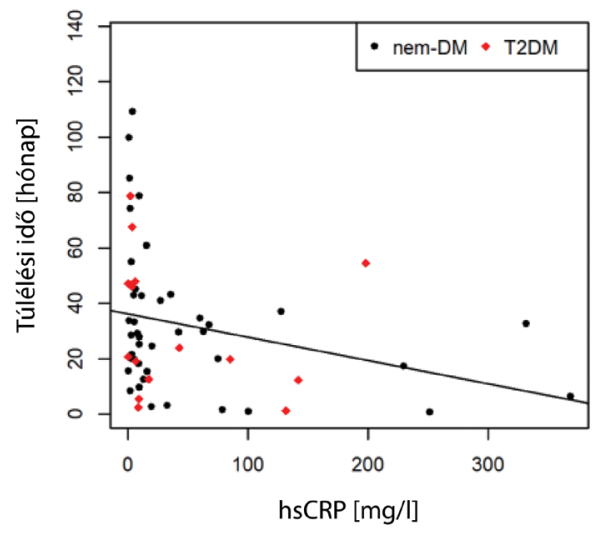

2. ábra

A magas-szenzitivitású C-reaktív protein (hsCRP-) méréssel rendelkező betegeknél ( $\mathrm{n}=57$ ) mért szérum-hsCRP-szintek korrelációs összefüggései A: a fehérvérsejt- $(R:+0,50, p=0,0007)$ és B: a thrombocytaszámokkal $(R:+0,57, p<0,0001)$, illetve C: a túlélési idővel $(R:-0,41, p=0,0132)$

áttétekkel szövődött esetek, a tumort megelőzően kialakult major cardiovascularis események, az ismert pajzsmirigybetegek és a vizsgálat ideje alatt bekövetkezett halálozások száma között nem volt eltérés a két csoportban (2. táblázat).

Vizsgáltuk a thrombocytaszámok, a túlélési idő, illetve a T2DM fennállási idejének korrelációs összefüggéseit a többi vizsgált paraméterrel is. Míg az első kettő esetében több szignifikáns összefüggést is igazolni tudtunk, addig a T2DM fennállási ideje és a többi paraméter között nem volt semmilyen statisztikailag kimutatható kapcsolat. Az összes beteg adatait együttesen vizsgálva, ahogy a thrombocytaszámok emelkedtek, a betegek túlélési ideje csökkent ( $\mathrm{R}:-0,35 ; \mathrm{p}=0,0085)$, ugyanakkor a fehérvérsejtek száma növekedett $(\mathrm{R}:+0,42 ; \mathrm{p}=0,0007)$. Az emelkedett fehérvérsejtszámok a betegek életkilátásait negatívan befolyásolták ( $\mathrm{R}:-0,41 ; \mathrm{p}=0,0010)$ ( 1 . ábra).

Habár az általunk vizsgált korábbi leletek között nem minden esetben volt mérve szérum-hsCRP-szint, az öszszes beteg körülbelül kétharmadánál $(\mathrm{n}=57)$ meg tudtuk vizsgálni, hogy a hsCRP - mint a gyulladásos folyamatok markere - mely paraméterekkel mutat kapcsolatot. A hsCRP-szintek emelkedésével növekedett a fehérvérsejt- $(\mathrm{R}:+0,50 ; \mathrm{p}=0,0007)$ és a thrombocytaszám $(\mathrm{R}$ :
$+0,57 ; \mathrm{p}<0,0001)$ is. Magasabb hsCRP-szintekhez alacsonyabb túlélési idók tartoztak $(\mathrm{R}:-0,41 ; \mathrm{p}=0,0132)$ (2. ábra).

\section{A primer tumor mütéti eltávolitását követöen 4-6 héttel a vizsgált paraméterek változásai}

Míg a primer tumor felismerésekor 86, CRC-s beteg adatai álltak rendelkezésünkre, addig a primer tumor mútéti eltávolítását követően 66 személy posztoperatív laboratóriumi adatai voltak elérhetők (nem-DM: 49 fö; T2DM: 17 fó). A pre- és posztoperatív állapotok közti változások elemzése során a betegek mütétet követő thrombocytaszáma szignifikánsan alacsonyabb volt (mütét előtt: $323,5 \pm 128,63$ giga/1, mútét után: 289,2 \pm $82,45$ giga/l, $\mathrm{p}=0,0232)$. A számított GFR szignifikánsan (mütét előtt: $80,2 \pm 24,60 \mathrm{ml} / \mathrm{min} / 1,73 \mathrm{~m}^{2}$, mütét után: $\left.87,0 \pm 23,43 \mathrm{ml} / \mathrm{min} / 1,73 \mathrm{~m}^{2}, \mathrm{p}=0,0232\right)$, a gamma-glutamil-transzferáz-szintek pedig marginálisan (mûtét előtt: $44,1 \pm 53,08 \mathrm{U} / 1$, mütét után: 73,7 \pm $122,49 \mathrm{U} / 1, \mathrm{p}=0,0610)$ magasabbak voltak a mütétet követően. A többi vizsgált laboratóriumi paraméter érdemben nem változott a mútétet követően (3. táblázat). 
3. táblázat $\mid$ Az összes beteg $(n=66)$ laboratóriumi paraméterei a primer tumor felfedezésekor, annak mútéti eltávolítását megelőzően, majd a primer tumor mútéti eltávolítását követően (átlag \pm szórás)

\begin{tabular}{|c|c|c|c|}
\hline Paraméter & Műtét előtt & Mütét után & p-érték \\
\hline Fehérvérsejt [giga/l] & $8,3 \pm 2,72$ & $7,7 \pm 2,62$ & n. s. \\
\hline Vörösvértest [tera/l] & $4,5 \pm 0,49$ & $4,4 \pm 0,52$ & n. s. \\
\hline Hemoglobin $[\mathrm{g} / 1]$ & $124,8 \pm 20,35$ & $122,2 \pm 17,70$ & n. s. \\
\hline Hematokrit $[1 / 1]$ & $0,38 \pm 0,050$ & $0,37 \pm 0,044$ & n. s. \\
\hline Thrombocyta [giga/l] & $323,5 \pm 128,63$ & $289,2 \pm 82,45$ & $\mathrm{p}=0,0232$ \\
\hline Vörösvértest-eloszlási szélesség (RDW) [\%] & $14,8 \pm 2,47$ & $15,1 \pm 2,12$ & n. s. \\
\hline Glutamát-oxálacetát-transzamináz (GOT) [U/l] & $22,7 \pm 13,17$ & $24,5 \pm 15,58$ & n. s. \\
\hline Glutamát-piruvát-aminotranszferáz (GPT) [U/l] & $24,5 \pm 21,47$ & $23,5 \pm 15,55$ & n. s. \\
\hline Gamma-glutamil-transzferáz (GGT) [U/l] & $44,1 \pm 53,08$ & $73,7 \pm 122,49$ & $\mathrm{p}=0,0610$ \\
\hline $\operatorname{eGFR}\left[\mathrm{ml} / \mathrm{min} / 1,73 \mathrm{~m}^{2}\right]$ & $80,2 \pm 24,60$ & $87,0 \pm 23,43$ & $\mathrm{p}=0,0232$ \\
\hline Éhomi vércukor $[\mathrm{mmol} / \mathrm{l}]$ & $6,0 \pm 1,60$ & $5,9 \pm 1,80$ & n. s. \\
\hline
\end{tabular}

eGFR = számított glomerularis filtrációs ráta; n. s. = nem szignifikáns

4. táblázat $\mid$ A nem cukorbeteg tumoros személyek $(\mathrm{n}=49)$ párosított laboratóriumi paraméterei a primer tumor felfedezésekor, annak mútéti eltávolítását megelőzően, majd a primer tumor mútéti eltávolítását követően (átlag \pm szórás)

\begin{tabular}{|c|c|c|c|}
\hline Paraméter & Mütét előtt & Mütét után & p-érték \\
\hline Fehérvérsejt [giga/l] & $8,0 \pm 2,45$ & $7,5 \pm 2,28$ & n. s. \\
\hline Vörösvértest [tera/1] & $4,5 \pm 0,48$ & $4,4 \pm 0,52$ & n. s. \\
\hline Hemoglobin $[\mathrm{g} / 1]$ & $126,3 \pm 20,00$ & $123,0 \pm 18,22$ & n. s. \\
\hline Hematokrit $[1 / 1]$ & $0,38 \pm 0,051$ & $0,38 \pm 0,046$ & n. s. \\
\hline Thrombocyta [giga/l] & $321,9 \pm 125,47$ & $292,4 \pm 85,25$ & $\mathrm{p}=0,1082$ \\
\hline Vörösvértest-eloszlási szélesség (RDW) [\%] & $15,0 \pm 2,60$ & $15,1 \pm 1,88$ & n. s. \\
\hline Glutamát-oxálacetát-transzamináz (GOT) [U/l] & $24,4 \pm 14,12$ & $23,3 \pm 11,61$ & n. s. \\
\hline Glutamát-piruvát-aminotranszferáz (GPT) [U/l] & $25,4 \pm 24,07$ & $23,0 \pm 12,55$ & n. s. \\
\hline Gamma-glutamil-transzferáz (GGT) [U/l] & $45,2 \pm 58,82$ & $64,4 \pm 93,36$ & n. s. \\
\hline $\mathrm{eGFR}\left[\mathrm{ml} / \mathrm{min} / 1,73 \mathrm{~m}^{2}\right]$ & $81,5 \pm 24,62$ & $85,9 \pm 20,83$ & n. s. \\
\hline Éhomi vércukor $[\mathrm{mmol} / \mathrm{l}]$ & $5,5 \pm 1,00$ & $5,2 \pm 0,63$ & n. s. \\
\hline
\end{tabular}

eGFR = számított glomerularis filtrációs ráta; n. s. = nem szignifikáns

5. táblázat | A 2-es típusú cukorbeteg tumoros személyek $(\mathrm{n}=17)$ laboratóriumi paraméterei a primer tumor felfedezésekor, annak mútéti eltávolítását megelőzően, majd a primer tumor mútéti eltávolítását követően (átlag \pm szórás)

\begin{tabular}{|c|c|c|c|}
\hline Paraméter & Mútét előtt & Mútét után & p-érték \\
\hline Fehérvérsejt [giga/1] & $8,9 \pm 3,41$ & $8,5 \pm 3,36$ & n. s. \\
\hline Vörösvértest [tera/l] & $4,5 \pm 0,53$ & $4,8 \pm 0,53$ & n. s. \\
\hline Hemoglobin $[\mathrm{g} / \mathrm{l}]$ & $120,2 \pm 21,32$ & $120,1 \pm 16,46$ & n. s. \\
\hline Hematokrit $[1 / 1]$ & $0,38 \pm 0,048$ & $0,37 \pm 0,043$ & n.s. \\
\hline Thrombocyta [giga/l] & $328,0 \pm 141,28$ & $279,9 \pm 75,43$ & $\mathrm{p}=0,0720$ \\
\hline Vörösvértest-eloszlási szélesség (RDW) [\%] & $14,4 \pm 2,12$ & $15,1 \pm 2,76$ & n. s. \\
\hline Glutamát-oxálacetát-transzamináz (GOT) [U/1] & $17,6 \pm 8,37$ & $28,1 \pm 23,77$ & n.s. \\
\hline Glutamát-piruvát-aminotranszferáz (GPT) [U/l] & $21,8 \pm 10,16$ & $25,0 \pm 22,42$ & n. s. \\
\hline Gamma-glutamil-transzferáz (GGT) [U/1] & $40,9 \pm 32,13$ & $101,4 \pm 186,77$ & n.s. \\
\hline eGFR $\left[\mathrm{ml} / \mathrm{min} / 1,73 \mathrm{~m}^{2}\right]$ & $76,4 \pm 24,94$ & $90,2 \pm 30,13$ & $\mathrm{p}=0,0634$ \\
\hline Éhomi vércukor [mmol/l] & $7,4 \pm 2,11$ & $7,6 \pm 2,58$ & n. s. \\
\hline
\end{tabular}

eGFR = számított glomerularis filtrációs ráta; $n$. s. = nem szignifikáns 
A: Primer tumor mútéti eltávolítását megelőző adatok alapján

Strata + Nem-DM-csoport + T2DM-csoport

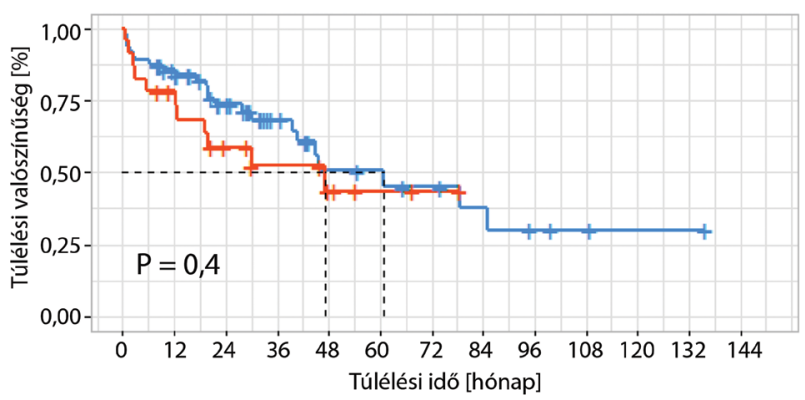

Túlélő esetek száma:

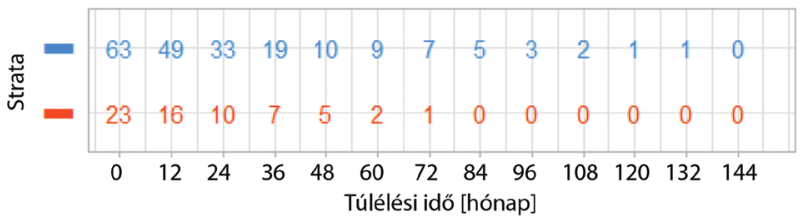

Elhunyt vagy 'elveszett' esetek száma:

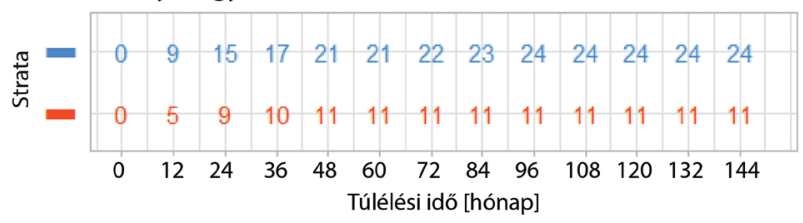

B: Primer tumor műtéti eltávolítását követő adatok alapján

Strata + Nem-DM-csoport + T2DM csoport

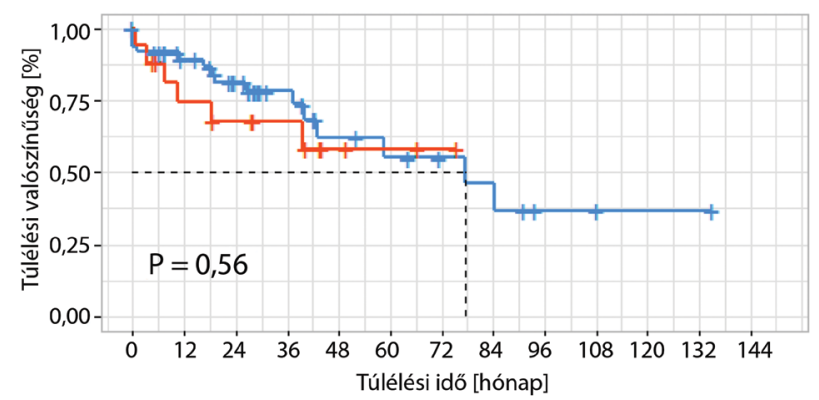

Túlélő esetek száma:

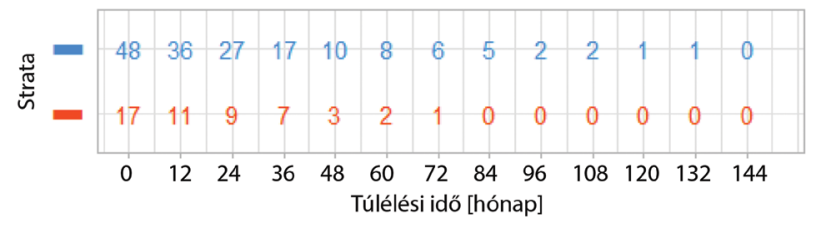

Elhunyt vagy 'elveszett' esetek száma:

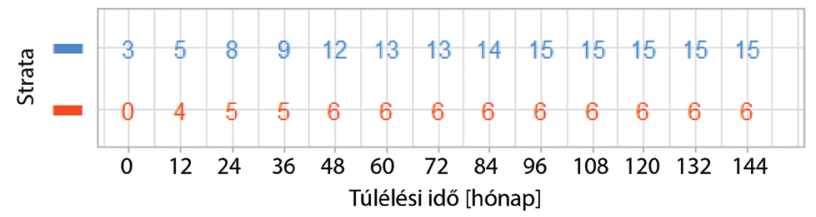

3. ábra $\mid$ Egyváltozós túlélési elemzés. A cukorbetegség önmagában sem A: a primer tumor mútéti eltávolítását megelőzően ( $\mathrm{p}=0,4020$ ), sem B: a mútétet követően $(\mathrm{p}=0,5590)$ nem szignifikáns befolyásoló tényező

Posztoperatív thrombocytosis (400 giga/l feletti thrombocytaszám) a betegek 10,6\%-ában (T2DM: 0 fó, nemDM: 7 fó) volt megfigyelhető, ami a 22,7\%-os kiindulási értékhez (T2DM: 3 fö, nem-DM: 12 fö) képest szignifikáns csökkenés $(\mathrm{p}=0,035 \mathrm{l})$.

$\mathrm{Az}$ összes beteg esetében megfigyelthez hasonlóan a thrombocytaszámok csökkenése figyelhető meg a nemDM- (mútét előtt: $321,9 \pm 125,47$ giga/1, mütét után: $292,4 \pm 85,25$ giga/1) és a T2DM- (mütét előtt: 328,0 $\pm 141,28$ giga/1, mútét után: $279,9 \pm 75,43$ giga/1) csoporton belül is, azonban ez a csökkenés statisztikailag nem szignifikáns (4. és 5. táblázat).

\section{A betegek túlélési adatainak elemzése}

Megvizsgáltuk, hogy a T2DM önállóan, egyéb befolyásoló tényezők nélkül hatással van-e a betegek teljes túlélési idejére (Kaplan-Meier-féle vagy egyváltozós túlélési elemzés). A T2DM önállóan sem a primer tumor mütéti eltávolítását megelőzően, ahol a vizsgált csoport részét képezték a legrosszabb állapotban lévő betegek is ( $\mathrm{p}=$ $0,4020)$, sem a mútétet követően $(\mathrm{p}=0,5590)$ nem befolyásolta szignifikánsan a túlélést (3. ábra).

A T2DM önálló, túlélést befolyásoló szerepének elemzését követően úgynevezett többváltozós túlélési elemzéseket (Cox-regresszió) is elvégeztünk, melyek segítségével információt kaphatunk a modellbe bevont paraméterek közös, túlélésre gyakorolt hatásáról. A modellbe vont paraméterek kiválasztásakor célunk volt, hogy mind a T2DM-et, mind a CRC-t befolyásoló, a betegségek progressziójára jellemző közös tényezóket keressünk. Végső modellünkben vizsgáltuk a betegek életkorának, a T2DM jelenlétének, a T2DM mellett gyakran előforduló hypertoniának, az áttéteknek és néhány laboratóriumi paraméternek az együttes, túlélést befolyásoló hatását. Az elemzést elvégeztük a primer tumor felismerésekor, annak mütéti eltávolítását megelőzően (6. táblázat), illetve a mütétet követően elérhető adatokkal is (7. táblázat). A preoperatív állapotokat jellemző modell kiértékelését követően felmerült a kérdés, hogy a 20 legrosszabb állapotú beteg bevonása milyen módon befolyásolhatja túlélési modellünk eredményét. Ennek tisztázására elvégeztük a preoperatív adatok kiértékelését úgy is, hogy e betegeket kizártuk. Az így kapott túlélési valószínúségi becslés sem különbözött a teljes betegszámmal elvégzett modell eredményétől.

A primer tumor felismerését követően 86 beteg adatai alapján, a preoperatív állapotokat jellemeztük (6. táblázat):

a) A teljes túlélés elsősorban az áttétek jelenlétekor csökken jelentősen (relatív kockázat [relative risk, RR]: 2,3064; $\mathrm{p}=0,0433)$.

b) Az áttétekhez hasonlóan a magasabb életkornak (évenkénti növekedés RR: 1,0708; $\mathrm{p}=0,0073$ ) és 
c) az emelkedett preoperatív thrombocytaszámoknak (egységenkénti emelkedés RR: 1,0043,p = 0,0023) is negatív hatása figyelhető meg a túlélésre.

d) A T2DM-nek a primer tumor eltávolítását megelőzően nincs szignifikáns befolyásoló hatása a betegek túlélésére.

A primer tumor mütéti eltávolítását követően, 66 beteg adatai alapján (7. táblázat):

a) A preoperatív modellhez hasonlóan a betegek magasabb életkora (évenkénti növekedés RR: 1,1029; $\mathrm{p}=0,0032)$ és

b) az emelkedett thrombocytaszámok (egységenkénti emelkedés RR: 1,0090, $\mathrm{p}=0,0098)$ szignifikáns befolyásoló tényezői a túlélésnek.

c) A mútétet követően a T2DM-nek és az áttéteknek a túlélésre gyakorolt szerepe megváltozik: a T2DM- ben is szenvedő CRC-s betegek teljes túlélésére a T2DM negatív hatással van. A rövidebb túlélési idő becsült valószínűsége szignifikánsan magasabb a betegség fennállása mellett, mint az a nem T2DM CRC-s betegek esetében megfigyelhető, mintegy ötszörösére növeli a korábbi halálozás kockázatát (RR: 5,1612; $\mathrm{p}=0,0165$ ).

d) A preoperatív modellhez képest az áttétek szerepe jelentősen változik. Míg a primer tumor mútéti eltávolítását megelőzően az (inoperábilis) áttétek előfordulási gyakorisága magasabb, illetve a preoperatív laboratóriumi és anamnesztikus adataikkal a csak palliatív terápiával kezelhető betegek is beletartoztak a vizsgálati populációba, addig a posztoperatív modellbe ezek a betegek nem kerültek bele. A primer tumor mútéti eltávolítását követően

6. táblázat | Többváltozós túlélési elemzés (Cox-regresszió) eredménye a primer tumor felismerésekor, annak mútéti eltávolítását megelőzően, 86 beteg adatai alapján (Wald-teszt: $\mathrm{p}=0,0047$, 'likelihood ratio' teszt: $\mathrm{p}=0,0032$ )

\begin{tabular}{|c|c|c|c|c|}
\hline Paraméter & Esetszám & Relatív kockázat (RR) & 95\%-os konfidenciaintervallum & p-érték \\
\hline Thrombocyta [giga/1] & - & 1,0043 & $(1,0015-1,0070)$ & $\mathrm{p}=0,0023$ \\
\hline Életkor [év] & - & 1,0708 & $(1,0187-1,1260)$ & $\mathrm{p}=0,0073$ \\
\hline $\begin{array}{l}\text { 2-es típusú diabetes: } \\
\text { - Van } \\
\text { - Nincs }\end{array}$ & $\begin{array}{l}23 \\
63\end{array}$ & 1,8120 & $(0,7720-4,2530)$ & n. s. \\
\hline $\begin{array}{l}\text { Antihypertensiv terápia: } \\
\text { - Van } \\
\text { - Nincs }\end{array}$ & $\begin{array}{l}59 \\
27\end{array}$ & 0,4667 & $(0,1667-1,3070)$ & n. $s$ \\
\hline $\begin{array}{l}\text { Áttét: } \\
\text { - Van } \\
\text { - Nincs }\end{array}$ & $\begin{array}{l}33 \\
53\end{array}$ & 2,3064 & $(1,0254-5,1880)$ & $\mathrm{p}=0,0433$ \\
\hline Vörösvértest-eloszlási szélesség (RDW) [\%] & - & 0,9392 & $(0,8048-1,0960)$ & n. s. \\
\hline $\mathrm{eGFR}\left[\mathrm{ml} / \mathrm{min} / 1,73 \mathrm{~m}^{2}\right]$ & - & 0,9706 & $(0,9407-1,0010)$ & $\mathrm{p}=0,0611$ \\
\hline Kreatinin $[\mu \mathrm{mol} / 1]$ & - & 0,9793 & $(0,9557-1,0040)$ & $\mathrm{p}=0,0943$ \\
\hline
\end{tabular}

eGFR = számított glomerularis filtrációs ráta; n. s. = nem szignifikáns

7. táblázat Többváltozós túlélési elemzés (Cox-regresszió) eredménye a primer tumor mútéti eltávolítását követően, 66 beteg adatai alapján (Wald-teszt: $\mathrm{p}=0,0034$, 'likelihood ratio' teszt: $\mathrm{p}=0,0006$ ).

\begin{tabular}{|c|c|c|c|c|}
\hline Paraméter & Esetszám & Relatív kockázat (RR) & 95\%-os konfidenciaintervallum & p-érték \\
\hline Thrombocyta [giga/l] & - & 1,0090 & $(1,0022-1,0160)$ & $\mathrm{p}=0,0098$ \\
\hline Életkor [év] & - & 1,1029 & $(1,0332-1,1770)$ & $\mathrm{p}=0,0032$ \\
\hline $\begin{array}{l}\text { 2-es típusú diabetes: } \\
\text { - Van } \\
\text { - Nincs }\end{array}$ & $\begin{array}{l}17 \\
49\end{array}$ & 5,1612 & $(1,3500-19,7320)$ & $\mathrm{p}=0,0165$ \\
\hline $\begin{array}{l}\text { Antihypertensiv terápia: } \\
\text { - Van } \\
\text { - Nincs }\end{array}$ & $\begin{array}{l}46 \\
20\end{array}$ & 0,2271 & $(0,0560-0,9210)$ & $\mathrm{p}=0,0380$ \\
\hline $\begin{array}{l}\text { Áttét: } \\
\text { - Van } \\
\text { - Nincs }\end{array}$ & $\begin{array}{l}26 \\
40\end{array}$ & 1,9091 & $(0,6175-5,9030)$ & n. s. \\
\hline Vörösvértest-eloszlási szélesség (RDW) [\%] & - & 1,2088 & $(0,9788-1,4930)$ & $\mathrm{p}=0,0782$ \\
\hline $\mathrm{eGFR}\left[\mathrm{ml} / \mathrm{min} / 1,73 \mathrm{~m}^{2}\right]$ & - & 0,9787 & $(0,9415-1,017)$ & n. s. \\
\hline Kreatinin $[\mu \mathrm{mol} / 1]$ & - & 0,9417 & $(0,8860-1,0010)$ & $\mathrm{p}=0,0533$ \\
\hline
\end{tabular}

eGFR = számított glomerularis filtrációs ráta; $n$. s. = nem szignifikáns 
az egyéb befolyásoló tényezőkhöz képest az áttétek túlélést befolyásoló szerepe csökken, és habár még mindig jelentős, közel kétszeres valószínúségi kockázatot jelent (RR: 1,9091, n. s.), a modell alapján mégsem befolyásolja szignifikánsan a túlélést.

e) A feltehetően hypertonia miatt antihypertensiv terápiában részesülő betegeknél a túlélési modellel végzett becslés alapján a hosszabb túlélési idő valószínúsége kb. 77\%-kal magasabb, mint azoknál, akik antihypertensiv gyógyszeres terápiában nem részesülnek ( $\mathrm{RR}: 0,2271, \mathrm{p}=0,0380)$.

\section{Megbeszélés}

A CRC-betegek jelentős többségénél emelkedik a thrombocyták száma, thrombocytosis alakul ki [12, 4143], melynek hátterében több feltételezett mechanizmus állhat $[15,44]$. A T2DM-ról is ismert, hogy a betegség progressziója során a thrombocyták diszfunkciója alakul ki [45-48]. Siegel és munkatársainak eredményei alapján a nem T2DM-személyekhez képest a colorectalis tumorok kialakulásának incidenciája T2DM jelenlétében emelkedett, körülbelül másfélszeres [19].

A CRC, a T2DM és a thrombocytosis közös összefüggéseit eddig még nem kutatták. Jelen tanulmányunkban ennek klinikai vonatkozásait vizsgáltuk retrospektív adatok elemzésével. A CRC-s betegek emelkedett thrombocytaszámait igazoltuk, melyek a primer tumor mútéti eltávolítását követően csökkentek. A CRC-ben leginkább érintett korcsoportban, a 60 év feletti személyeknél a különböző becslések alapján körülbelül minden ötödik személy T2DM-beteg [17, 18]. Az általunk vizsgált, CRC-ben szenvedő betegpopulációban minden harmadik személy T2DM-beteg volt. A T2DM-személyek laboratóriumi és anamnesztikus paramétereit a nem T2DM-betegekével összehasonlítva, nem tudtunk igazolni a két csoport között olyan számottevő eltérést, mely magyarázattal szolgálhatott volna a T2DM-csoportban megfigyelt thrombocytosis alacsonyabb elöfordulási gyakoriságára.

Túlélési modellekkel vizsgáltuk, hogy a T2DM önmagában vagy további, laboratóriumi és anamnesztikus tényezők bevonásával együttesen milyen hatással van a betegek teljes túlélési idejére. A T2DM önálló, túlélést befolyásoló szerepét a jelen populáció vizsgálatával nem tudtuk igazolni, azonban a primer tumor mütéti eltávolítására alkalmas betegeknél, a mútétet követően egyéb tényezőkkel együttesen vizsgálva, a T2DM okozta, szignifikánsan magasabb, rövidebb túlélési valószínúségeket igazoltunk. A primer tumor mütéti eltávolítását megelőzően az áttétek túlélést csökkentő szerepe a legjelentősebb. A mútétet követően az áttétek túlélést befolyásoló szerepe csökken, többváltozós modellünkben a vizsgált paraméterek közül a T2DM ötszörös, rövidebb túlélési időt prognosztizáló kockázati tényezővé vált. Li és mtsai [49] CRC-s betegek bevonásával elvégzett, a T2DM túlélésre gyakorolt hatását vizsgáló 21 korábbi közlemény metaanalízisét végezték el. Analízisük alapján a T2DMés CRC-s személyeknél a teljes túlélési idő szignifikánsan alacsonyabb (esélyhányados: 1,247; 95\%-os konfidenciaintervallum [KI]: 1,185-1,312), mint a nem T2DMCRC-seknél. A metaanalízisükhöz kiválasztott vizsgálatokban a betegek követési ideje 2,67 és 15,6 év között változott (medián). A teljes túlélési adatok mellett vizsgálták mind a tumorspecifikus túlélési adatokat (esélyhányados: 1,132; 95\% KI: 0,925-1,384), mind a bármilyen egyéb okból bekövetkező mortalitást (esélyhányados: 1,233; 95\% KI: 1,111-1,367). Az egyéb okból bekövetkező mortalitás eredménye alapján a szerzókben felmerült a kérdés, hogy a betegek alacsonyabb túlélését a T2DM a tumoros betegséggel való kapcsolata miatt rontja-e, vagy valamilyen egyéb, a T2DM-mel kapcsolatos komorbiditás alakult-e ki a háttérben. Hippisley-Cox és munkacsoportja [50] a nói és férfi CRC-betegeket külön-külön vizsgálta abból a szempontból, hogy a T2DM milyen szerepet játszik a betegek túlélésében. Mindkét nem esetén rövidebb túlélési idóket igazoltak T2DM jelenlétében (nók: esélyhányados: 1,12; 95\%-os KI 1,021,23; férfiak: esélyhányados: 1,14 ; 95\%-os KI 1,051,24), mint a nem T2DM-személyeknél. Li [49], illetve Hippisley-Cox [50] munkacsoportjának eredményét, a T2DM-et mint önálló, a túlélést befolyásoló tényezőt saját vizsgálati csoportunkban nem tudtuk alátámasztani, de ez a minta méretével is összefüggésben lehet.

A T2DM túlélésre gyakorolt hatása szempontjából igen fontos lenne a betegek aktuális cukoranyagcsere-állapotának jellemzése, melyet a $\mathrm{HbA}_{1 \mathrm{C}}$-szintek vizsgálatával lehetne jellemezni. A rendezett cukor-anyagcseréjü $\left(\mathrm{HbA}_{\mathrm{lC}} \leq 8,0 \%\right)$ betegekével szemben a különböző komorbiditások fokozott megjelenése ismert a rosszabb cukoranyagcsere-helyzetü betegeknél. Az elérhető archív adatokban nem találtunk elegendő mennyiségü $\mathrm{HbA}_{\mathrm{lC}^{-}}$ értéket ahhoz, hogy a túléléssel és a thrombocytosissal kapcsolatos összefüggéseket vizsgáljuk. Túlélési elemzésekben a jól és rosszul kezelt T2DM-betegek különválasztását kiemelt jelentőségünek tartjuk.

Habár mind a T2DM, mind a CRC jelentős egészségügyi - és gazdasági - probléma, a két betegség közös előfordulásával kapcsolatban kevés nemzetközi adat áll rendelkezésre, melyekkel jelen vizsgálatunk adatait öszszevethetnénk. T2DM-ben a CRC másfélszeres incidenciáját igazolták korábban [19]. Megfigyeléseinket nagyobb vizsgálati mintaelemszámmal, esetleg további paraméterek, mint például a T2DM-betegek aktuális anyagcserehelyzetének, a CRC lokációjának vagy a T2DM kezelési módjának bevonásával az eredmények pontosítását, a T2DM, a CRC és a thrombocytosis közös összefüggéseinek szélesebb körú vizsgálatát tartjuk szükségesnek.

\section{Következtetés}

Eredményeinket röviden összegezve, a vizsgált CRC-betegekben emelkedett thrombocytaszámot igazoltunk, mely a primer tumor eltávolítását követően szignifikán- 
san csökkent. Körülbelül minden harmadik CRC-s beteg 2-es típusú cukorbetegségben is szenvedett. A T2DMcsoportban alacsonyabb gyakorisággal figyeltünk meg thrombocytosist, mint a nem-DM-csoportban. Többváltozós túlélési modellben a T2DM és az emelkedett thrombocytaszámok a primer tumor sebészi eltávolítását követően szignifikáns, rövidebb túlélési időre prognosztizáló kockázati tényezők.

Megfigyeléseink arra utalnak, hogy az emelkedett thrombocytaszámok és a T2DM a colorectalis daganatok felismerésekor prognosztikai jelként értékelhetők.

Anyagi támogatás: A közlemény megírását, illetve a kapcsolódó kutatómunkát az NFKIH K-116128 és a Magyar Diabetes Társaság kutatási pályázata támogatta.

Szerzői munkamegosztás: H. Z.: A kézirat megírása, irodalomkutatás, a betegadatok gyújtése, statisztikai elemzés és értékelés. A. V.: A betegadatok gyújtése, irodalomkutatás. H. M.: A betegadatok gyưjjtése, statisztikai elemzés és értékelés. H. Gy.: Tanácsadás a klinikai jellemzőkről. I. P., H. L.: A kézirat lektorálása. S. A.: Kutatásvezető, témafelvetés, a kézirat lektorálása, a közlemény koncepciójának megalkotása. A cikk végleges változatát valamennyi szerző elolvasta és jóváhagyta.

Érdekeltségek: A szerzőknek nincsenek érdekeltségeik.

\section{Irodalom}

[1] Trousseau A. Phlegmasia alba dolens. In: Lectures on clinical medicine. Vol. 5. New Sydenham Society, London, 1865; pp. 281-332.

[2] Camerer E, Qazi AA, Duong DN, et al. Platelets, protease-activated receptors, and fibrinogen in hematogenous metastasis. Blood 2004; 104: 397-401.

[3] Labelle M, Begum S, Hynes RO. Direct signaling between platelets and cancer cells induces an epithelial-mesenchymal-like tran sition and promotes metastasis. Cancer Cell 2011; 20: 576-590.

[4] Nieswandt B, Hafner M, Echtenacher B, et al. Lysis of tumor cells by natural killer cells in mice is impeded by platelets. Cancer Res. 1999; 59: 1295-1300

[5] Palumbo JS, Talmage KE, Massari JV, et al. Platelets and fibrin(ogen) increase metastatic potential by impeding natural killer cell-mediated elimination of tumor cells. Blood 2005; 105: $178-185$.

[6] Schumacher D, Strilic B, Sivaraj KK, et al. Platelet-derived nucleotides promote tumor-cell transendothelial migration and metastasis via $\mathrm{P}_{2} \mathrm{Y}_{2}$ receptor. Cancer Cell 2013; 24: 130-137.

[7] Wahrenbrock M, Borsig L, Le D, et al. Selectin-mucin interactions as a probable molecular explanation for the association of Trousseau syndrome with mucinous adenocarcinomas. J Clin Invest. 2003; 112: 853-862.

[8] Bockhorn M, Jain RK, Munn LL. Active versus passive mechanisms in metastasis: do cancer cells crawl into vessels, or are they pushed? Lancet Oncol. 2007; 8: 444-448.

[9] Fidler IJ. Critical determinants of metastasis. Semin Cancer Biol. 2002; 12: 89-96.

[10] Erdemir F, Kilciler M, Bedir S, et al. Clinical significance of platelet count in patients with renal cell carcinoma. Urol Int. 2007; 79: $111-116$
[11] Heng S, Benjapibal M. Preoperative thrombocytosis and poor prognostic factors in endometrial cancer. Asian Pac J Cancer Prev. 2014; 15: 10231-10236.

[12] Monreal M, Fernandez-Llamazares J, Piñol M, et al. Platelet count and survival in patients with colorectal cancer - a preliminary study. Thromb Haemost. 1998; 79: 916-918.

[13] Shimada H, Oohira G, Okazumi S, et al. Thrombocytosis associated with poor prognosis in patients with esophageal carcinoma. J Am Coll Surg. 2004; 198: 737-741.

[14] Taucher S, Salat A, Gnant M, et al. Impact of pretreatment thrombocytosis on survival in primary breast cancer. Thromb Haemost. 2003; 89: 1098-1106.

[15] Baranyai Z, Josa V, Toth A, et al. Paraneoplastic thrombocytosis in gastrointestinal cancer. Platelets 2016; 27: 269-275.

[16] Ogurtsova K, da Rocha Fernandes JD, Huang Y, et al. IDF Diabetes Atlas: Global estimates for the prevalence of diabetes for 2015 and 2040. Diabetes Res Clin Pract. 2017; 128: 40-50.

[17] IDF Diabetes Atlas, 8th edn. International Diabetes Federation, Brussels, Belgium, 2017. Available from: http://www.diabetesatlas.org [accessed: November 14, 2017].

[18] Kempler P, Putz Z, Kiss Z, et al. Prevalence and financial burden of type 2 diabetes mellitus in Hungary between 2001-2014 results of the analysis of the National Health Insurance Fund database. [A 2-es típusú diabetes előfordulása és költségterheinek alakulása Magyarországon 2001-2014 között - az Országos Egészségbiztosítási Pénztár adatbázis-elemzésének eredményei.] Diabetologia Hung. 2016; 24: 177-188. [Hungarian]

[19] Siegel RL, Miller KD, Jemal A. Cancer statistics, 2016. CA Cancer J Clin. 2016; 66: 7-30.

[20] Giovannucci E, Harlan DM, Archer MC, et al. Diabetes and cancer: a consensus report. CA Cancer J Clin. 2010; 60: 207-221.

[21] Shlomai G, Neel B, LeRoith D, et al. Type 2 diabetes mellitus and cancer: the role of pharmacotherapy. J Clin Oncol. 2016; 34: 4261-4269.

[22] Singh S, Earle CC, Bae SJ, et al. Incidence of diabetes in colorectal cancer survivors. J Natl Cancer Inst. 2016; 108: djv402.

[23] Tsilidis KK, Kasimis JC, Lopez DS, et al. Type 2 diabetes and cancer: umbrella review of meta-analyses of observational studies. BMJ 2015; 350: g7607.

[24] Halmos T, Suba I. Type 2 diabetes and metabolic syndrome as conditions leading to malignant tumors. [A metabolikus szindróma és a 2-es típusu diabetes mellitus mint rosszindulatú daganatra hajlamosító állapotok.] Orv Hetil. 2008; 149: 2403-2411. [Hungarian]

[25] Rosta A. Diabetes and cancer risk: oncologic considerations. [Diabetes és rákkockázat az onkológus szemszögéből.] Orv Hetil. 2011; 152: 1144-1155. [Hungarian]

[26] Farmer RE, Ford D, Forbes HJ, et al. Metformin and cancer in type 2 diabetes: a systematic review and comprehensive bias evaluation. Int J Epidemiol. 2017; 46: 728-744.

[27] Jermendy G. New clinical data with metformin therapy in patients with diabetes mellitus. [Új klinikai adatok a cukorbetegek metforminterápiájával kapcsolatban.] Orv Hetil. 2010; 151: 2025-2030. [Hungarian]

[28] American Diabetes Association. 8. Cardiovascular disease and risk management. Diabetes Care 2015; 38(Suppll): S49-S57.

[29] Santilli F, Pignatelli P, Violi F, et al. Aspirin for primary prevention in diabetes mellitus: from the calculation of cardiovascular risk and risk/benefit profile to personalised treatment. Thromb Haemost. 2015; 114: 876-882.

[30] Mátyus J, Oláh A, Fodor B, et al. Information for laboratory specialists about the introduction of calculated GFR (eGFR), from the Hungarian Laboratory Diagnostic Society and the Hungarian Nephrology Society. [A Magyar Laboratóriumi Diagnosztikai Társaság és a Magyar Nephrológiai Társaság tájékoztatója laboratóriumi szakemberek számára a számított GFR (eGFR) bevezetésével kapcsolatos ismeretekrôl.] Magyar Labo- 
ratóriumi Diagnosztikai Társaság és a Magyar Nephrológiai Társaság, 2007. [Hungarian]

[31] R Core Team: R: A language and environment for statistical computing. R Foundation for Statistical Computing, Vienna, 2017.

[32] R Studio Team. RStudio: Integrated development for R. RStudio, Inc., Boston, MA, 2015.

[33] Dinya E. Biometrics in medical practice. [Biometria az orvosi gyakorlatban.] Medicina Könyvkiadó, Budapest, 2001. [Hungarian]

[34] Reiczigel J, Harnos A, Solymosi N. Biostatistics for non-statisticians. [Biostatisztika nem statisztikusoknak.] Pars Kft., Nagykovácsi, 2010. [Hungarian]

[35] Benjamini Y, Hochberg Y. Controlling the false discovery rate: a practical and powerful approach to multiple testing. J Royal Stat Soc Series B (Methodological) 1995; 57: 289-300.

[36] Dinya E, Solymosi N. Clinical biometrics 2. [Biometria a klinikumban 2. - Feladatok megoldása R-környezetben.] Medicina Kiadó, Budapest, 2016. [Hungarian]

[37] Clark TG, Bradburn MJ, Love SB, et al. Survival analysis, part I: basic concepts and first analyses. Br J Cancer 2003; 89: 232-238.

[38] Therneau T. A package for survival analysis in R. 2015

[39] Kassambara A, Kosinski M. Survminer: Drawing survival curves using 'ggplot2'. 2017.

[40] Grambsch PM, Therneau TM. Proportional hazards tests and diagnostics based on weighted residuals. Biometrika 1994; 81: 515-526.

[41] Baranyai Z, Josa V, Krzystanek M, et al. Evaluation of thrombocytosis as predictive factor in colorectal cancer. [A thrombocytosis mint prediktív faktor értékelése colorectalis tumorokban.] Magy Seb. 2013; 66: 331-337. [Hungarian]
[42] Baranyai Z, Krzystanek M, Josa V, et al. The comparison of thrombocytosis and platelet-lymphocyte ratio as potential prognostic markers in colorectal cancer. Thromb Haemost. 2014; 111: $483-490$.

[43] Josa V, Krzystanek M, Eklund AC, et al. Relationship of postoperative thrombocytosis and survival of patients with colorectal cancer. Int J Surg. 2015; 18: 1-6.

[44] Stone RL, Nick AM, McNeish IA, et al. Paraneoplastic thrombocytosis in ovarian cancer. N Engl J Med. 2012; 366: 610-618.

[45] Ferreiro JL, Gomez-Hospital JA, Angiolillo DJ. Platelet abnormalities in diabetes mellitus. Diab Vasc Dis Res. 2010; 7: 251259.

[46] Yazbek N, Bapat A, Kleiman N. Platelet abnormalities in diabetes mellitus. Coron Artery Dis. 2003; 14: 365-371

[47] Kraakman MJ, Lee MK, Al-Sharea A, et al. Neutrophil-derived S100 calcium-binding proteins A8/A9 promote reticulated thrombocytosis and atherogenesis in diabetes. J Clin Invest. 2017; 127: 2133-2147.

[48] Lee RH, Bergmeier W. Sugar makes neutrophils RAGE: linking diabetes-associated hyperglycemia to thrombocytosis and platelet reactivity. J Clin Invest. 2017; 127: 2040-2043.

[49] Li J, Liu J, Gao C, et al. Increased mortality for colorectal cancer patients with preexisting diabetes mellitus: an updated metaanalysis. Oncotarget 2017; 8: 62478-62488.

[50] Hippisley-Cox J, Coupland C. Development and validation of risk prediction equations to estimate survival in patients with colorectal cancer: cohort study. BMJ 2017; 357: j2497.

(Herold Zoltán, Budapest, Szentkirályi u. 46., 1088 e-mail: herold.zoltan@med.semmelweis-univ.hu)

\section{"Cuivis dolori remedium est patientia." (Publilius Syrus) (Minden fájdalomra ír a türelem.)} feltéve, hogy az eredeti szerző és a közlés helye, illetve a CC License linkje és az esetlegesen végrehajtott módosítások feltüntetésre kerülnek. 